\title{
Middle East Moho Relief Estimation Using Spherical Prisms in Gravity Inversion
}

\author{
Parastoo Jalooli ${ }^{1}$, Hossein Zomorrodian ${ }^{*, 1}$, Hamid Reza Siahkoohi ${ }^{2}$ \\ (1) Department of Earth Sciences, Science and Research Branch, Islamic Azad University, Tehran, Iran, \\ P.jalooli@srbiau.ac.ir, h.zomorrodian@srbiau.ac.ir \\ (2) Institute of Geophysics, University of Tehran, Tehran, Iran, hamid@ut.ac.ir
}

Article history: received April 28, 2019; accepted October 15, 2020

\begin{abstract}
Study of Moho in Middle East and surrounding region is of great importance for geoscientists. The area contains parts of the Eurasian, Indian, African and Arabian plates as well as active tectonic structures which made it rich in geodynamic and tectonic interests. In this study we investigated Moho relief in the Middle East region using gravity and seismic data. Regarding the extent of the study area, spherical prism (tesseroid) modeling is used to calculate the gravity effect of the topography and crustal anomalies. Determining of Moho depth from gravity data is a nonlinear inverse problem. We inverted the gravity data using Uieda's inversion method where the process was constrained by the available seismic data over the study region. The effect of topography and crustal sediments were excluded using global topography and crustal models.

The resulting Moho relief is in accordance with plate boundaries and correlates well with the prominent tectonic features of the Middle East region. According to the results, the thinnest part of the crust found to be about $12 \mathrm{~km}$ in the Indian Ocean and the thickest part appeared in the west of Tibetan plateau with depths of about $54 \mathrm{~km}$. In some parts of the study area discrepancies were seen between our results and Moho depths from seismological studies these differences are most probably caused by different approaches used in the different studies. Since we imposed smoothness by regularization on estimated Moho map, this can also be additional source of the discrepancies.
\end{abstract}

Keywords: Gravity inversion; Moho Depth; Tectonics, Plate Boundary; Middle-East.

\section{Introduction}

The Middle East region extends from eastern Mediterranean to the Arabian Sea and has a rich geological history that stretches back to the Proterozoic [Mart, 2013]. This area is a collection of different geodynamic and tectonic structures, each one with its own complex nature, and of great importance for scientific studies. This region contains parts of the Eurasian, Indian, African and Arabian plates as the large plates and some small plates [Bird, 2003]. Figure 1 shows prominent geodynamics of the Middle East. In this region there are different types of boundary interactions like oceanic divergent boundary in the Red Sea, continental divergent boundary in East African rift, oceanic-continental subduction in Makran, Zagros thrust belt, north and east Anatolian fault, just to mention a few. 


\section{Parastoo Jalooli et al.}

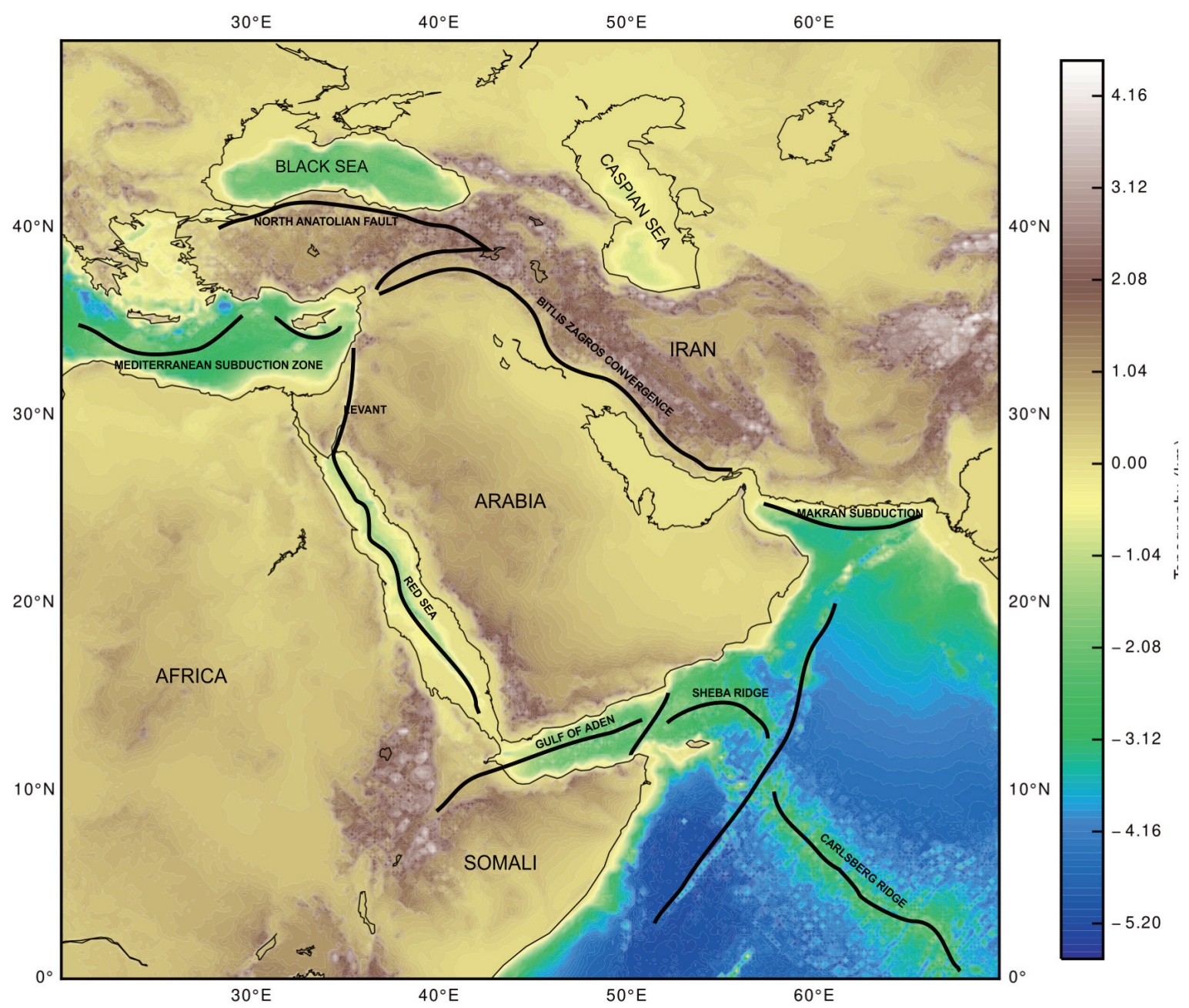

Figure 1. Topography map of Middle East from ETOPO1, with most significant tectonic features. (After Mart (2013) with some modification).

One of the most significant tectonic features for study is the Mohorovic discontinuity (Moho) which is the boundary surface between the crust and the mantle. Moho surface characteristics, including the depth, density contrast between crust and upper mantle, shear wave velocity, just to name a few, were evaluated all over the world by gravimetric, thermal, and seismic methods like CRUST1.0 [Laske et al., 2013], LITHO1.0 [Pasyanos et al., 2014] and GEMMA [Reguzzoni et al., 2015]. Over the study area there are vast amount of published studies such as: East African rift system and Afar Triangle related researches [e.g. Dugda et al., 2005; Tiberi et al., 2007; Hammond et al., 2011; Seber et al., 2001; Almadani, 2011; Globig et al., 2016].

Moho depth and crustal studies have been carried out in Red Sea and Gulf of Aden [e.g. Tiberi et al., 2005; Hansen et al., 2007; Salem et al., 2013]. There are also studies in Arabian plate [e.g. Al-Hashmi et al., 2011; Al-Damegh et al., 2005; Mechie et al., 2013].

Numerus researches have been done over Iran region like Dehghani and Makris, [1984]; shad-Manamman et al., [2011]; Motaghi et al., [2012]; Mohammadi et al., [2013]; Ebadi et al., [2019] and Heydarizadeh Shali et al. [2020]. There are also studies that concentrated on specific tectonic structures in Iran like Zagros and Makran [e.g. Afsari et al., 2011; Paul et al., 2011; Tatar \& Nasrabadi, 2011; Abdollahi et al., 2018 and Nasrabadi et al., 2019]. Some of them discussed Alborz Mountain [e.g. Sodoudi et al., 2009; Radjaee et al., 2010; Motavalli-Anbaran et al., 2011 and Motavalli-Anbaran et al., 2013].

There are also variety of studies in Anatolian, Aegean and Mediterranean region [e.g. Saunders et al., 1998; Li et al., 2003; Van der Meijde et al., 2003; Starostenke et al., 2004; Zhu et al., 2006; Tezel et al., 2013; Karabulut et al., 2013; Sampietro et al., 2018 and Karabulut et al., 2019]. 
Presence of Global Geopotential Models in the satellite era, made the access to gravimetric regular grid data feasible all over the earth. In gravimetric studies over the large area (similar to the area of interest in this study) using rectangular prisms will not take into account the curvature of the earth. Since the study region is larger than $15^{\circ} \times 15^{\circ}$, tesseroids will produce more accurate results in comparison with prisms in an acceptable computation time [Wild-Pfeiffer, 2008]. In this paper we aim to determine continues model for Moho in the Middle East area by isolating the gravitational effect of Moho relief and then inverting data using tesseroids. Existing Moho depths from seismological studies over the study area will be used to validate the results.

\section{Methodology}

To estimating the relief of the Moho from gravity data, first one must obtain the gravitational effect of the target anomalous density distribution attributed to the Moho relief, and then apply the appropriate inverse method. This requires eliminating all gravity effects other than that of the target anomalous density from observed data. Since real Moho undulates around a reference Moho (Moho of the Normal Earth, an ellipsoidal reference Earth) the first correction is to remove the gravity of an ellipsoidal reference Earth $(\gamma)$. The gravity disturbance $\delta g$ is determined by subtracting the normal gravity $\gamma(\mathrm{P})$ of reference ellipsoid WGS84 from the observed gravity at the same point "P" on the earth:

$$
\delta g(\mathrm{P})=\mathrm{g}(\mathrm{P})-\gamma(\mathrm{P})
$$

The obtained disturbance $\delta g$, as shown in Figure 2, contains all masses attributed to the topography as well as the mass deficiency corresponding to the oceans and sedimentary basins, crustal sources, heterogeneities below the upper mantle, and the effect of the difference between the real Moho topography and the Moho of the Normal Earth [Uieda et al., 2016]. Next, total Bouguer effect at point "P" is obtained by eliminating the gravity effect of topography and oceanic masses from gravity disturbance $(\delta g)$, using ETOPO1 digital train models [Amante and Ekins, 2009]:

$$
\delta g_{B}=\delta g(\mathrm{P})-g_{\text {Topo }}(\mathrm{P})
$$

To remove the gravitational effect of known sedimentary basins (the effects of other crustal and mantle sources, shown in (Figure 2-d), are assumed to be negligible) the gravity effect of three sediment layers is estimated by using CRUST1.0 [Laske et al., 2013] crustal model. During the corrections, the standard density of $2670^{\mathrm{kg}} / \mathrm{m}^{3}$ and $-1630 \mathrm{~kg} / \mathrm{m}^{3}$ are used for continents and oceans, respectively and CRUST1.0 densities for sediments.

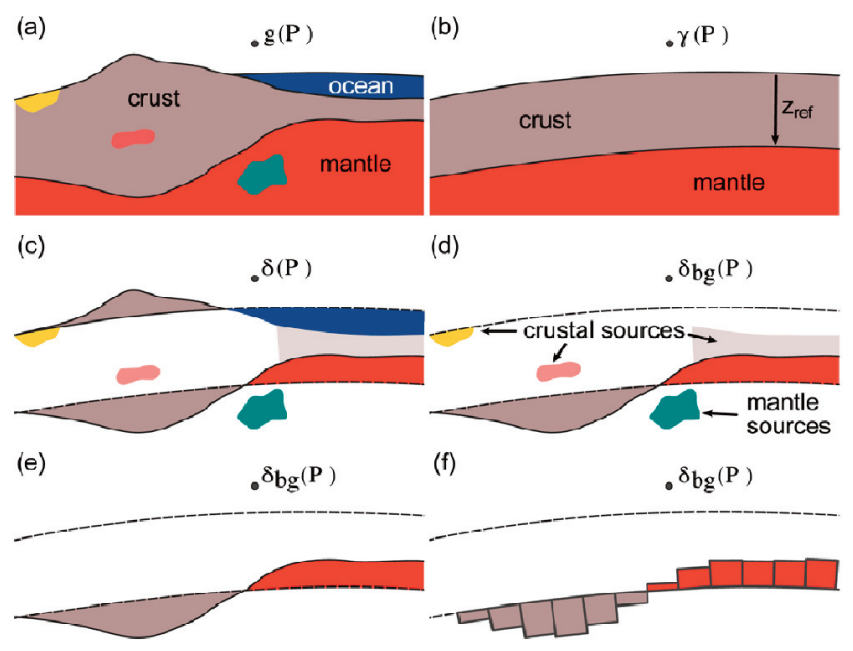

Figure 2. Gravity reduction and correction steps to isolate the anomalous Moho gravitational attraction (Uieda et al., 2016). 


\section{Parastoo Jalooli et al.}

$$
\delta g_{I}=\delta g_{B}-g_{\text {sediments }}
$$

Gravitational effects of above mentioned reductions and corrections are calculated by forward modeling in a spherical Earth approximation using tesseroids. Each utilized tesseroid is a spherical mass element bounded by two meridians, two parallels and two co-center spheres. There are two approaches for calculating gravitational effect of tesseroids. One is based on Taylor series expansion [Hech and Seitz, 2007], and the other is based on GaussLegendre integration [Asgharzadeh et al., 2007]. In this paper we used the modified version of the second approach [Uieda et al., 2015 and Uieda, 2013]. The residuals of all applied reduction and correction steps represents the gravity effect of the anomalous Moho relief (Figure 2-e) that will serve as an input data for inversion procedure.

\subsection{Discretization of problem and inversion}

In order to perform forward modeling to calculate the gravity attraction of the anomalous Moho relief during the inversion procedure, one needs to discretize the real Moho into $\mathrm{N} \times \mathrm{M}$ spherical prisms (Figure 2-f).

Here we used the inversion method introduced by Uieda and Barbosa [2016]. They merged the effective Bott's [Bott, 1960] method with smoothness regularization and a discretization of the anomalous Moho into tesseroids (spherical prisms). Since in this method the absolute value of the density-contrasts of the tesseroids is a fixed parameter, then Moho gravity anomaly will be a nonlinear function of tesseroids depth:

$$
d_{i}=f_{i}(k)
$$

where $\mathrm{d}_{\mathrm{i}}$ is the $i$ th element of $\mathrm{N}$-dimensional predicted data vector, $\mathrm{k}$ is M-dimensional parameter vector including M Moho depths $\left(h_{p}\right), f_{i}$ is the $i$ th nonlinear function that maps parameters onto data. These functions are radial component of the gravitational attraction of the tesseroids.

We estimate the parameter vector $\mathbf{p}$ from a set of observed gravity data $\mathbf{d}_{\mathbf{o}}$ in a least-squares sense which minimizes the data-misfit function or fidelity term $\varphi(\mathbf{p})$ :

$$
\varphi(\mathbf{p})=\left[\mathbf{d}_{\mathbf{o}}-\mathbf{d}(\mathbf{p})\right]^{\mathrm{T}}\left[\mathbf{d}_{\mathbf{o}}-\mathbf{d}(\mathbf{p})\right]
$$

Since estimation of the Moho depths from a set of observed gravity data is an ill-posed non-linear inversion problem (Silva et al. 2001), however under some assumptions the uniqueness of the solution is guaranteed [Sampietro and Sanso, 2012]. We needed to perform a regularized least-squares non-linear inversion in this study. First-order Tikhonov regularization [Tikhonov and Arsenin, 1977] is used to impose smoothness on the solution.

$$
\Gamma(\mathbf{p})=\varphi(\mathbf{p})-\mu \theta(\mathbf{p})
$$

Where $\mu$ is regularization parameter and $\theta$ is the smoothness penalty functional which is given by:

$$
\theta(\mathbf{p})=\mathbf{p}^{\mathrm{T}} \mathbf{R}^{\mathrm{T}} \mathbf{R} \mathbf{p}
$$

Here $\mathbf{R}$ is an $1 \times \mathrm{m}$ finite-difference matrix representing 1 first order differences between the depths of adjacent tesseroids. The goal function $\Gamma(\mathbf{p})$ is also nonlinear with respect to $\mathbf{p}$ and can be minimized using the Gauss-Newton method.

Apart from Moho depths, we need to estimate three hyper parameters [Uieda and Barbosa, 2016] namely the regularization parameter $(\mu)$, Moho reference level $\left(h_{n}\right)$ and density contrast $(\Delta \rho)$. They have been estimated in two steps during the inversion by holdout-cross validation method [Kim, 2009]. The holdout approach first divides the observed data into two groups of training and testing sets. Training set is used for inversion procedure while testing set is used for evaluating the quality of above mentioned parameters. Mean Square Error (MSE) is also used to select inversion parameters optimally. The inversion was performed using hyperparameters: reference level $\left(h_{n}=32.5 \mathrm{~km}\right)$, density contrast $\left(\Delta \rho=500 \mathrm{~kg} / \mathrm{m}^{3}\right)$ and regularization parameter $(\mu=1 e-10)$, determined during cross validation step. 


\section{Data Sources}

The gravity data used in this study are generated from satellite only spherical harmonic model EIGEN-6S4-V2 [Förste and Bruinsma, 2016] up to degree and order 300 (the model combines data from GOCE, GRACE and LAGOS satellites). The data were downloaded from the International Center for Global Earth Models (ICGEM) [Barthelmes and Kohler, 2012] in the form of the complete gravity field on a regular grid with $0.2^{\circ}$ grid spacing at ellipsoidal height of $50 \mathrm{~km}$.

The gravitational effect of topography and sediment basin was removed using spherical Earth approximation via utilizing spherical prisms. The effects are calculated using ETOPO1 digital terrain model [Amante and Eakins, 2009], CRUST1.0 [Laske et al., 2013] and standard densities of $2670 \mathrm{~kg} / \mathrm{m}^{3}$ for continents and $-1630 \mathrm{~kg} / \mathrm{m}^{3}$ for oceans. The sediment-free Bouguer disturbance is obtained after subtracting the gravitational effect of topography and sediment basin from gravity disturbance by ignoring all other crustal sources.

The seismic information extracted from different seismological studies over the Middle East region including 448 Moho depths are shown in Table 1. The estimated Moho depths from our proposed method later on are validated by these seismic data. Figure 3 shows the sediment-free Bouguer disturbance and location of seismic Moho depths.

\begin{tabular}{|c|c|c|}
\hline References & Method & Area \\
\hline Karabulut et al. [2013] & Receiver function studies & Turkey \\
\hline Tezel et al. [2013] & Receiver function studies & Turkey \\
\hline Zhu et al. [2006] & Receiver function studies & Aegean region \\
\hline Al-Damegh et al. [2005] & Receiver function studies & Arabian Plate \\
\hline Mohsen et al. [2005] & Receiver function studies & Dead Sea \\
\hline Tiberi et al. [2007] & Receiver function studies & Gulf of Aden \\
\hline Ahmed et al. [2013] & Receiver function studies & Western Yemen \\
\hline Al-Hashmi et al. [2011] & Receiver function studies & Arabian Peninsula \\
\hline Afsari et al. [2011] & Teleseismic Ps & Iran \\
\hline Motaghi et al. [2015] & Receiver function studies & Iran \\
\hline Motaghi et al. [2012] & Receiver function studies & Northeast Iran \\
\hline Radjaee et al. [2010] & Receiver function studies & Alborz, Northern Iran \\
\hline Tatar and Nasrabadi [2013] & Joint inversion & Zagros, Iran \\
\hline Gok et al. [2006] & Receiver Functions and Surface Wave Dispersion & Iraq \\
\hline Geissler et al. [2008] & Receiver function studies & Eastern Europe \\
\hline
\end{tabular}

Table 1. Moho depths from seismological studies utilized in this study. 


\section{Parastoo Jalooli et al.}

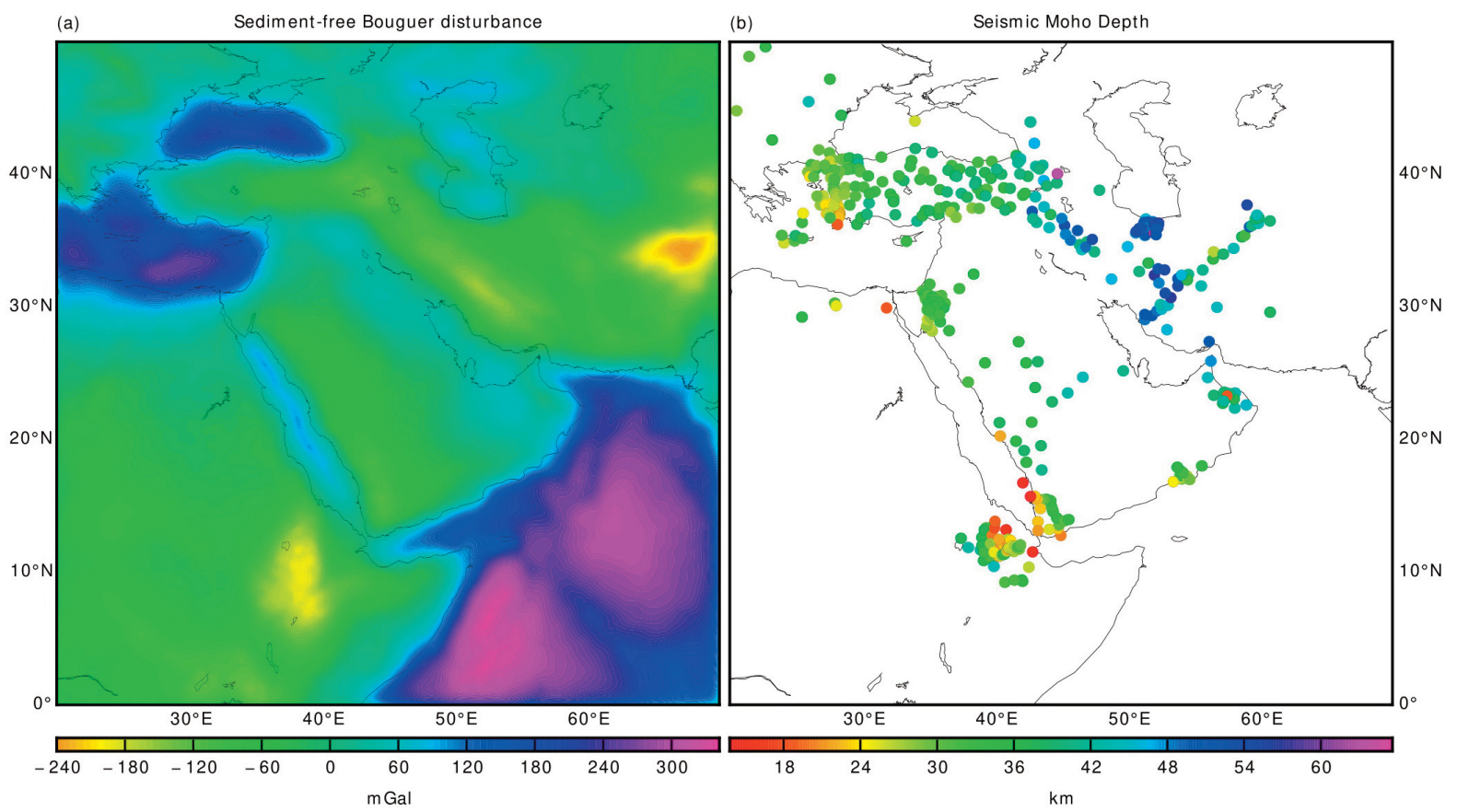

Figure 3. a) Sediment-free Bouguer disturbance that is the input data for inversion. b) Location and depth of seismic Moho depths using in this study.

\section{Results and Discussion}

As mentioned earlier the study area, Middle East region, contains significant plate boundaries such as The African-Arabian divergent boundary located in the red sea, Arabian-Eurasian convergent boundary forming Zagros Mountains belt, African-Anatolian and Aegean Sea subduction zone in the Mediterranean Sea, African-Somalian divergent boundary, Arabian-Indian convergent and Indian-Somalian divergent boundaries in the Indian ocean. In this Section we concentrate on the observed correlations between above mentioned features and the Moho discontinuity map obtained from current study. The estimated Middle East Moho map is shown in Figure 4, where we adopted Peter Bird's digital model [Bird, 2003] to demonstrate main lithospheric plates. One of the iconic divergent boundaries located in the middle of the Red Sea rift is African-Arabian boundary. Our estimated Moho in Red Sea (Figure 4) well correlates with the African-Arabian boundary and topography of this area which indicates that the area and surrounding regions are in isostatic compensation. The estimated Moho depth is about $22 \mathrm{~km}$ in northern Red Sea and the Red sea rift shows its characteristic by the shallow depth at about $22 \mathrm{~km}$ in the middle of the Red Sea. The Moho starts thickening through flank margins and coasts which extends to about $\sim 26-30 \mathrm{~km}$. In the western continental margins the depth of the Moho is increased to $\sim 38$ and becomes thicker toward south in the northwest of East African Rift system and 38-40 km in eastern continental margin in Arabian plat and increases to $\sim 44 \mathrm{~km}$ in southwestern Arabian coast. We observed eastward decreasing of the Moho depth in Gulf of Aden from almost 25 to $20 \mathrm{~km}$, and sharp increasing in Moho depth from the middle of the Gulf of Aden to continental coasts northward and southward from $\sim 20 \mathrm{~km}$ to $\sim 38 \mathrm{~km}$. We estimated the Moho depth of $\sim 32 \mathrm{~km}$ beneath the Afar triangle. The thick part of Moho ( 40 to $50 \mathrm{~km}$ ) is seen beneath the west and 38 to $46 \mathrm{~km}$ beneath the east of the main Ethiopian rift system. The Moho decreases to almost $30 \mathrm{~km}$ in the east of main Ethiopian rift toward the northeast coast of the Africa and also decreases with high gradient from $30 \mathrm{~km}$ to $16 \mathrm{~km}$ in the east coast margins of Africa. In the west of highlands of main Ethiopian rift the average Moho is estimated to be about $30 \mathrm{~km}$. Arabian-SomalianIndian boundaries meet in Sheba ridge. The Moho depth is obtained about $22 \mathrm{~km}$ beneath the Sheba ridge and increases toward the coastal plains. According to Figure 4 the Indian-Somalia boundary, the northern part of the Indian mid ocean Ridges (Carlsberg Ridge), shows its northwest-southeast characteristics with obvious increase in depth, about $10 \mathrm{~km}$, from the surrounding oceanic crust. The study area also contains the oceanic part of the Indian 
plate where the Indian-Arabian divergent boundary is located at the north west of this plate. Moho depth in other parts of the Indian Ocean estimated in the range of 12 to $18 \mathrm{~km}$.

We obtained the average Moho depth of about $34 \mathrm{~km}$ beneath the Arabian plate, the Moho increases beneath the west and southwest of the Arabian plate to $44 \mathrm{~km}$ and well correlates to topography of the region, and shows the isostasy compensation in the region. The Moho depth increases to $38 \mathrm{~km}$ beneath the northern Arabian-Eurasian boundary in Zagros Mountain and becomes thinner, about $20 \mathrm{~km}$, south of this boundary in Makran subduction zone.

Our results indicate the thick Moho with average depth of about $46 \mathrm{~km}$ beneath the Zagros Mountain Belt with northwest-southeast trend, and the maximum value of estimated Moho depth in this region is about $50 \mathrm{~km}$. Decreasing of Moho depth to about $34 \mathrm{~km}$ is seen toward northeast to Central Iran. In the northeast of Iran Moho depth reaches to about $\sim 42 \mathrm{~km}$ beneath the Kopeh-Dagh Mountain. The south eastern part of the Arabian-Eurasian boundary is Makran subduction zone where the Arabian oceanic crust moves beneath the Eurasian continental crust and located in Oman Sea, in the south coast of Iran and Pakistan. The Moho depth estimated about $22 \mathrm{~km}$ beneath the boundary located in Makran. It increasing northward to about $30 \mathrm{~km}$ in the Oman coast and $40 \mathrm{~km}$ in southern Iran. In this study we do not see any obvious increment for Moho depth in the Alborz Mountain and the Moho depth in this area was found to be about $40 \mathrm{~km}$. Our results are more close to the results of Radjaee et al. [2010], that is, if there is any crustal root for Alborz Mountain, it is inadequate to say this region is in isostatic compensation, but still needs more research to be clarified.

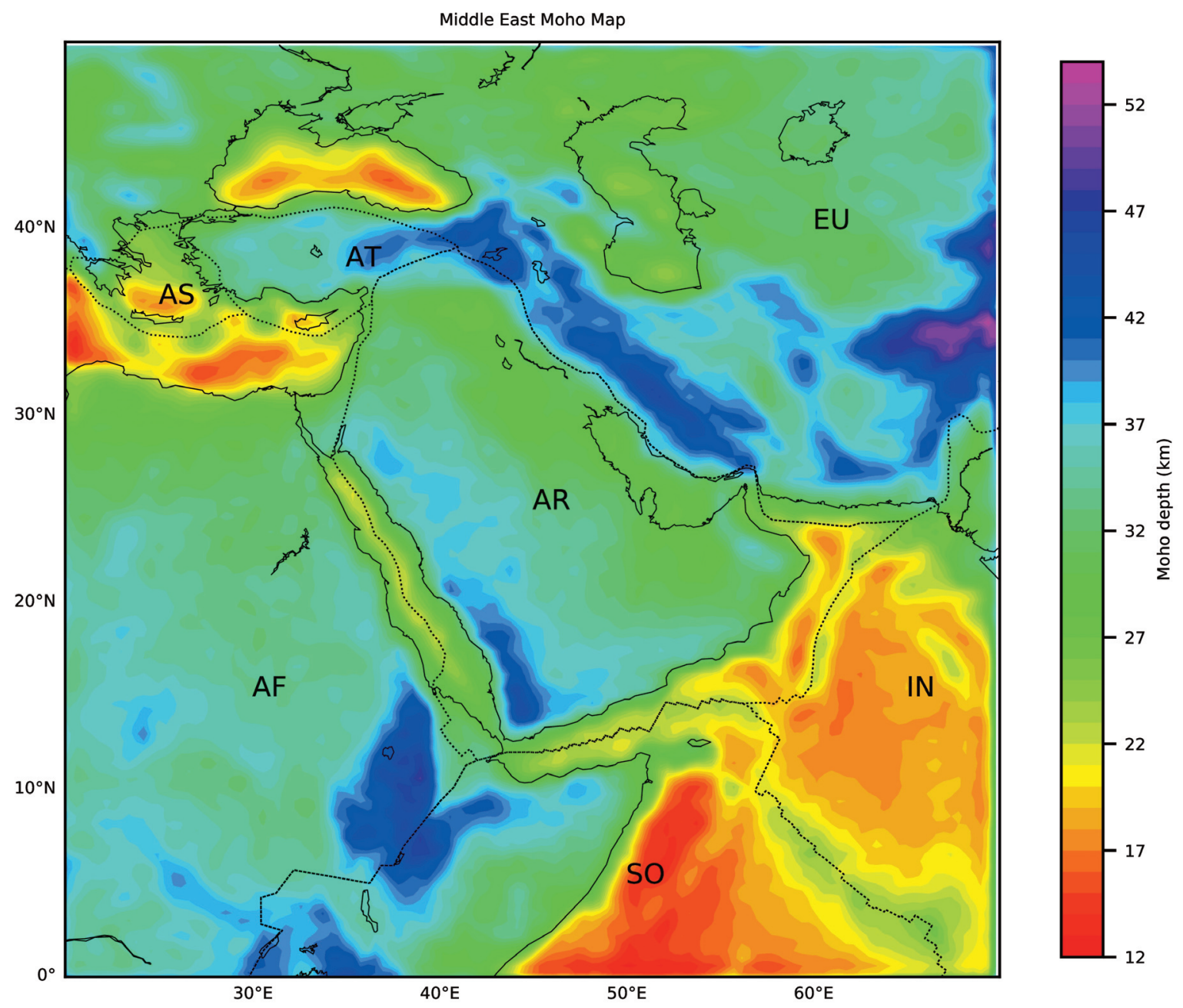

Figure 4. Continues Moho map of Middle East. Dotted lines show the plate boundaries. On the map AF=African plate, $\mathrm{AR}=$ Arabian plate, $\mathrm{EU}=$ Eurasian plate, $\mathrm{IN}=\mathrm{Indian}$ plate, $\mathrm{SO}=$ Somalian plate, $\mathrm{AT}=$ Anatolian plate and $\mathrm{AS}=$ Aegean Sea plate. 


\section{Parastoo Jalooli et al.}

In the northwest of study region there are Anatolian and Aegean Sea plates. The correlation between AnatolianEurasian boundaries with North Anatolian Fault which is observed in this study is in accordance with Zhu et al., [2004] observations and indicate decreasing of Moho depth westward from $\sim 42 \mathrm{~km}$ in the eastern part of Anatolian Plate to $\sim 28 \mathrm{~km}$ beneath Aegean-Anatolian boundary. In the north and central parts of the Aegean Sea plate the Moho depth observed to be in the range of 30 to $24 \mathrm{~km}$, decreasing southward to about $18 \mathrm{~km}$ in the north of the Crete Island, then increases to about $24 \mathrm{~km}$ beneath the Aegean Sea-Mediterranean boundary.

In Mediterranean Sea there is a subduction zone where the African plate moves beneath the Anatolian and Aegean Sea plates. The Moho depth in the deepest part of the Mediterranean Sea obtained in the range of $12 \mathrm{~km}$ and is in a good correlation with subduction trenches in this region. Southward to the northern African coasts, the Moho depth increases to $22 \mathrm{~km}$ in North African margins and increases up to $26 \mathrm{~km}$ in North African continent. Our estimated Moho depth is about $22 \mathrm{~km}$ in the eastern cost of the Mediterranean Sea located in Levant and increases to about $32 \mathrm{~km}$ beneath the Arabian-African boundary. In this study the Moho depth beneath the eastern and western Black Sea estimated to be $\sim 14 \mathrm{~km}$ and $\sim 16 \mathrm{~km}$, respectively. Beneath the northeastern and northwestern part of the Black Sea the Moho depth increases to about $30 \mathrm{~km}$. Our investigation showed that in the southern Black sea the Moho depth increases sharply from $\sim 18 \mathrm{~km}$ to about $26 \mathrm{~km}$ in the northern Anatolian coasts. In the west of the study area, in Eurasian plate, which is the west parts of the Tibetan plateau, we observed the maximum Moho depth about $54 \mathrm{~km}$. In the northern parts of the study area in Eurasian plate and north of Caspian Sea the average Moho depth estimated to be about $30 \mathrm{~km}$.

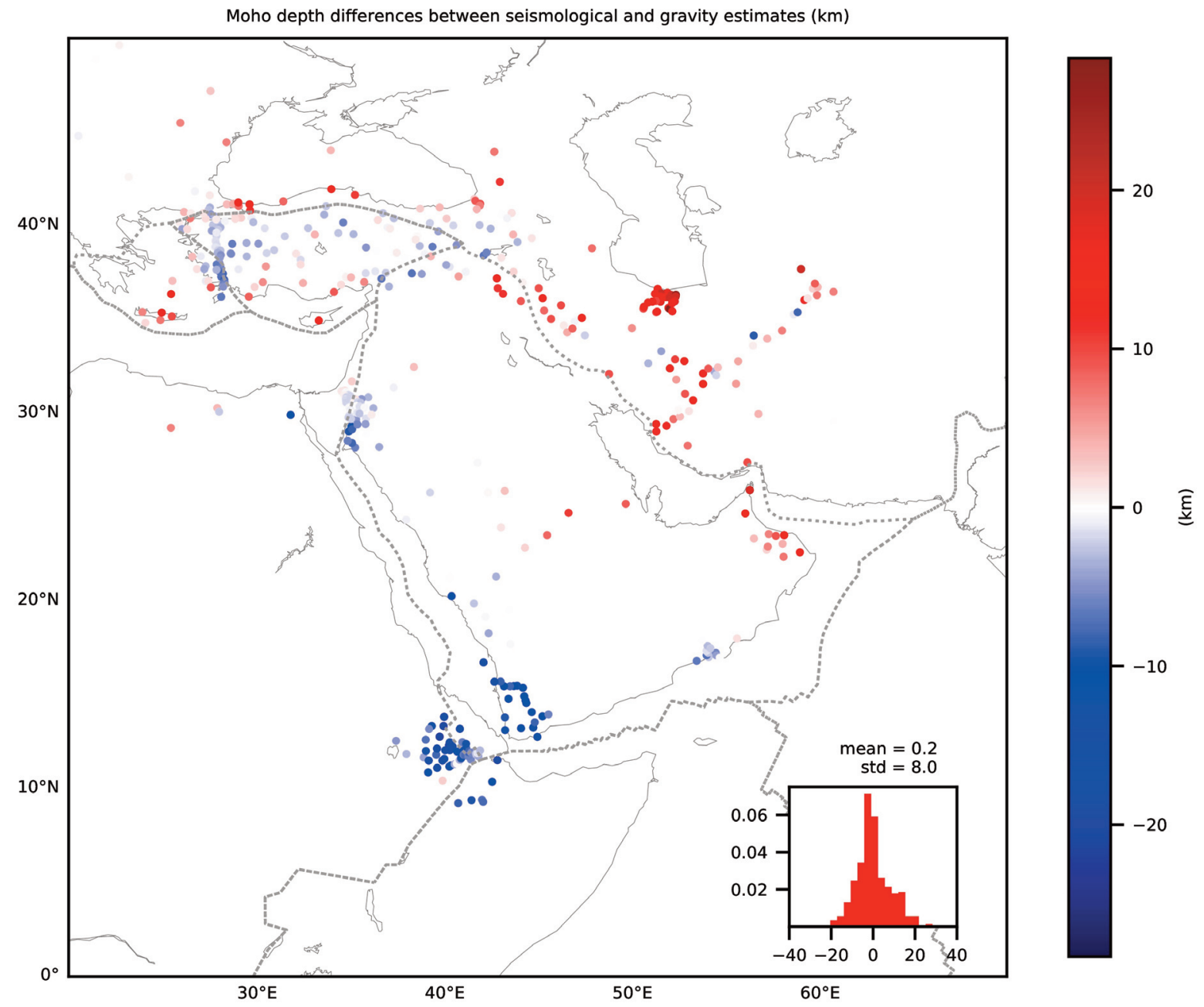

Figure 5. Differences between Moho depths from seismological studies and current study. 


\section{Conclusion}

In this study the Middle East Moho map was determined with an efficient inversion method and considering spherical earth by replacing rectangular prisms with tesseroids. The resulted gravity residuals and correlation of the Moho depths with geological and tectonic structures of the study region show the performance of the inversion procedure that adapt in this study. The differences between Moho depths estimated in this investigation and those determined by seismological studies are mostly due to smoothness we imposed by regularization on estimated Moho map and different approaches used to determine the Moho depths. The realistic Moho depth model from employing of detailed sediment description will fluctuate around the Moho depth model obtained in current study. The main cause of such fluctuation arises from employing of CRUST 1.0 model and imposing smoothness by Tikhonov regularization on solution of the inversion in this study.

In addition, we ignored crustal anomalies and considered certain density values for the oceans and continents. The smallest discrepancy happened in Arabian plate, Anatolian and Aegean Sea plates and the maximum discrepancy was seen in some parts of Zagros and Alborz mountains, as well as in some parts of the African rift.

The estimated Moho map also showed a good correlation with topography of the region, this indicates the acceptable performance of the adapted inversion procedure and utilizing of spherical prisms. This correlation could be interpreted as the fact that almost the whole region is in an isostatic compensation, but there are areas that do not show acceptable correlation like Alborz Mountain. The estimated Moho depth for the study area ranges from $12 \mathrm{~km}$ in the deepest parts of Indian Ocean up to $54 \mathrm{~km}$ in profound parts of the Tibetan plateau.

Acknowledgment. The authors would like to thank Dr. M. Tatar for his useful comments that improved this paper and Dr. Uieda for making the open source python program and packages publically available [Uieda, 2017].

\section{References}

Abdollahi, S., V. E. Ardestani, H. Zeyen and Z. H. Shomali (2018). Crustal and upper mantle structures of Makran subduction zone, SE Iran by combined surface wave velocity analysis and gravity modelling, Tectonophysics, 747, 191-210.

Afsari, N., F. Sodoudi, F. Taghizadeh, F. Farahmand and M. R. Ghassemi (2011). Crustal structure of Northwest Zagros (Kermanshah) and Central Iran (Yazd and Isfahan) using teleseismic Ps converted phases, J. Seismol., 15(2), 341-353.

Ahmed, A., C. Tiberi, S. Leroy, G. Stuart, D. Keir, J. Sholan, K. Khanbari, I. Al-Ganad, and C. Basuyao (2013). Crustal structure of the rifted volcanic margins and uplifted plateau of Western Yemen from receiver function analysis, Geophys. J. Int., 193, 1673-1690.

Al-Damegh, K., E. Sandvol and M. Barazangi (2005). Crustal structure of the Arabian plate: New constraints from the analysis of teleseismic receiver functions, Earth Planet. Sci. Lett., 231, 177-196.

Al-Hashmi, S., R. Gök, K. Al-Toubi, Y. Al-Shijbi, I. El-Hussain and A. J. Rodgers (2011). Seismic velocity structure at the southeastern margin of the Arabian Peninsula, Geophys. J. Int., 186(2), 782-792.

Almadani, S. A. (2011). Receiver function studies of crustal structure, composition, and evolution beneath the Afar Depression, Ethiopia, Doctoral Dissertation.

Amante, C. and B. W. Eakins (2009). ETOPO1 1 Arc-Minute Global Relief Model: Procedures, Data Sources and Analysis, NOAA Technical Memorandum NESDIS NGDC-24, National Geophysical Data Center, NOAA.

Asgharzadeh, M. F., R. R. B. von Frese, H. R. Kim, T. E. Leftwich and J. W. Kim (2007). Spherical prism gravity effects by Gauss-Legendre quadrature integration, Geophys. J. Int., 169(1), 1-11.

Barthelmes, F. and W. Kohler (2012). International Centre for Global Earth Models (ICGEM), J. Geod., 86(10), 932934.

Bird, P. (2003). An updated digital model of plate boundaries, Geochem., Geophys. Geosyst., 4(3), 1027.

Bott, M.H.P. (1960). The use of rapid digital computing methods for direct gravity interpretation of sedimentary basins, Geophysical Journal International, 3(1), 63-67.

Dehghani, G. A. and J. Makris (1984). The gravity field and crustal structure of Iran, N. Jb.Geol. Palaeont. Abh., 168, 


\section{Parastoo Jalooli et al.}

215-229.

Dugda, M. T., A. A. Nyblade, J. Julia, C. A. Langston, C. J. Ammon and S. Simiyu (2005). Crustal structure in Ethiopia and Kenya from receiver function analysis: Implications for rift development in eastern Africa, J. Geophys. Res., 110, B01303.

Ebadi, S., I. Barzaghi, A. Safari and A. Bahroudi (2019). Evaluation of different gravimetric methods to Moho recovery in Iran, Ann. Geophys., 62(5).

Förste, C., and S. L. Bruinsma (2016). EIGEN-6S4: A time-variable satellite-only gravity field model to d/o 300 based on LAGEOS, GRACE and GOCE data from the collaboration of GFZ Potsdam and GRGS Toulouse. | GFZpublic | http://doi.org/10.5880/icgem.2016.004.

Geissler, W.H., R. Kind and X. Yuan (2008). Upper Mantle and Lithospheric Heterogeneities in Central and Eastern Europe Seen by Teleseismic Receiver Functions, Geophys. J. Int., 174, 1-26.

Globig, J., M. Fernàndez, M. Torne, J. Vergés, A. Robert and C. Faccenna (2016). New insights into the crust and lithospheric mantle structure of Africa from elevation, geoid, and thermal analysis, J. Geophys. Res.: Solid Earth, 121, 5389-5424.

Gok, R., M. Pasyanos and E. Zor (2006). Lithospheric structure of the continent-continent collision zone: Eastern Turkey, Geophys. J. Int., 169, 1079-1088.

Hammond, J.O.S., J. M. Kendall, G. W. Stuart, D. Keir, C. Ebinger, A. Ayele and M. Belachew (2011). The nature of the crust beneath the afar triple junction: evidence from receiver functions, Geochem., Geophys., Geosyst., 12(12).

Hansen, S. E., A. J. Rodgers, S. Y. Schwartz and A. M. S. Al-Amri (2007). Imaging ruptured lithosphere beneath the Red Sea and Arabian Peninsula, Earth Planet. Sci. Lett., 259(3-4), 256-265.

Heck, B., and K. Seitz (2007). A comparison of the tesseroid, prism and pointmass approaches for mass reductions in gravity field modelling, J. Geod., 81(2), 121-136.

Heydarizadeh Shali, H., D. Sampietro, A. Safari, M. Capponi and A. Bahroudi (2020). Fast collocation for Moho estimation from GOCE gravity data: the Iran case study, Geophys. J. Int., 221(1), 651-664.

Karabulut, H., A. Paul, T. A. Ergun, D. Hatzfeld, D. M. Childs and M. Aktar (2013). Long-wavelength undulations of the seismic Moho beneath the strongly stretched Western Anatolia, Geophys. J. Int., 194(1), 450-464.

Karabulut, H., A. Paul, A. Değer Özbakır, T. Ergün and S. Şentürk (2019). A new crustal model of the Anatolia-Aegean domain: evidence for the dominant role of isostasy in the support of the Anatolian plateau, Geophys. J. Int.,218(1), 57-73.

Kim, J.H. (2009). Estimating classification error rate: repeated crossvalidation, repeated hold-out and bootstrap, Comput. Stat. Data Anal., 53(11), 3735-3745.

Laske, G., G. Masters, Z. Ma and M. Pasyanos (2013). Update on CRUST1. 0-A 1-degree global model of Earth's crust, In Geophys. Res. Abstr, (15), 2658.

Li, X., G. Bock, A. Vafidis, R. Kind, H. P. Harjes, W. Hanka, K. Wylegalla, M. Van der Meijde, X. Yuan, (2003). Receiver function study of the Hellenic subduction zone: imaging crustal thickness variations and the oceanic Moho of the descending African lithosphere, Geophys. J. Int., 155(2), 733-748.

Mart, Y. (2013). Geodynamics of the Middle East domain since the Oligocene: research summary, J. Geol. Soc. London, $170,483-496$.

Mechie, J., Z. Ben-Avraham, M. H. Weber, H. J. Götze, I. Koulakov, A. Mohsen and M. Stiller (2013). The distribution of Moho depths beneath the Arabian plate and margins, Tectonophysics, 609, 234-249.

Mohammadi, N., F. Sodoudi, E. Mohammadi and A. Sadidkhouy (2013). New constraints on lithospheric thickness of the Iranian plateau using converted waves, J. Seismol., 17(3), 883-895.

Mohsen, A., R. Hofstetter, G. Bock, R. Kind, M. Weber, K. Wylegalla and G. Rümpker (2005). A receiver function study across the Dead Sea Transform, Geophys. J. Int., 160, 948-960.

Motaghi, K., M. Tatar and K. Priestley (2012). Crustal thickness variation across the northeast Iran continental collision zone from teleseismic converted waves, J. Seismol., 16, 253-260.

Motaghi, K., M. Tatar, K. Priestley, F. Ramonelli, C. Doglioni and G. F. Panza (2015). The deep structure of the Iranian plateau, Gondwana Res., 28, 407-418.

Motavalli-Anbaran, S.H., H. Zeyen, M. F. Brunet and V. E. Ardestani (2011). Crustal and lithospheric structure of the Alborz Mountains, Iran, and surrounding areas from integrated geophysical modelling, Tectonics, 30(5).

Motavalli-Anbaran, S.H., H. Zeyen and V. E. Ardestani (2013). 3D joint inversion modeling of the lithospheric density structure based on gravity, geoid and topography data - Application to the Alborz Mountains (Iran) and South 
Caspian Basin region, Tectonophysics, 586, 192-205.

Nasrabadi, A., M. R. Sepahvand and Z. Dadjo (2019). Moho depth variations and Vp/Vs ratios in the seismotectonic zones of Central Iran, Eastern Iran, and Makran: using a modified Zhu and Kanamori method, J. Seismol., 23(4), 839-851.

Pasyanos, M. E., T. G. Masters, G. Laske and Z. Ma (2014). LITHO1. 0: An updated crust and lithospheric model of the Earth, J. Geophys. Res.: Solid Earth, 119(3), 2153-2173.

Paul, A., D. Hatzfeld, A. Kaviani, M. Tatar and C. Pequegnat (2010). Seismic imaging of the lithospheric structure of the Zagros mountain belt (Iran), In: Leturmy, P. and C. Robin, (Eds.), Tectonic and stratigraphic evolution of Zagros and Makran during the Mesozoic-Cenozoic, Geol. Soc. London, Special Publications, 330, 5-18.

Radjaee, A.H., D. Rham, M. Mokhtari, M. Tatar, K. Priestley and D. Hatzfeld (2010). Variation of Moho depth in the Central part of Alborz Mountains, North of Iran, Geophys. J. Int., 181, 173-184.

Reguzzoni, M. and D. Sampietro (2015). GEMMA: An Earth crustal model based on GOCE satellite data, International J. Appl. Earth Obs. Geoinfo., 35, 31-43.

Salem, A., C. Green, S. Campbell, J. D. Fairhead, L. Cascone and L. Moorhead (2013). Moho depth and sediment thickness estimation beneath the Red Sea derived from satellite and terrestrial gravity data, Geophysics, 78(5), 89-101.

Sampietro, D., A. Mansi and M. Capponi (2018). Moho Depth and Crustal Architecture beneath the Levant Basin from Global Gravity Field Model, Geosciences, 8(6), 200.

Sampietro, D. and F. Sansò (2012). Uniqueness theorems for inverse gravimetric problems. In VII Hotine-Marussi Symposium on Mathematical Geodesy, 111-115.

Sanders, P., K. Priestly and T. Taymaz (1998). Variation in the crustal structure beneath western Turkey, Geophys. J. Int., 134, 373-389.

Seber, D., E. Sandvol, C. Sandvol, C. Brindisi and M. Barazangi (2001). Crustal model for the Middle East and North Africa region: Implications for the isostatic compensation mechanism, Geophys. J. Int., 147, 630-638.

Shad Manaman, N., H. Shomali and K. Hemin (2011). New constraints on upper-mantle S-velocity structure and crustal thickness of the Iranian plateau using partitioned waveform inversion, Geophys. J. Int., 184, $247-267$.

Silva, J., W. Medeiros and V. Barbosa (2001). Potential-field inversion: choosing the appropriate technique to solve a geologic problem, Geophysics, 66(2), 511-520.

Sodoudi, F., X. Yuan, R. Kind, B. Heit and A. Sadidkhouy (2009). Evidence for a missing crustal root and a thin lithosphere beneath the Central Alborz by receiver function studies, Geophys. J. Int., 177(2), 733-742.

Starostenko, V., V. Buryanov, I. Makarenko, O. Rusakov, R. Stephenson, A. Nikishin, G. Georgiev, M. Gerasimov, R. Dimitriu, O. Legostaeva, V. Pchelarov and C. Sava (2004). Topography of the crust-mantle boundary beneath the Black Sea Basin, Tectonophysics, 381(1-4), 211-233.

Taghizadeh-Farahmand, F., N. Afsari and F. Sodoudi (2014). Crustal Thickness of Iran Inferred from Converted Waves, Pure Appl. Geophys., 172(2), 309-331.

Tatar, M. and A. Nasrabadi (2013). Crustal thickness variations in the Zagros continental collision zone (Iran) from joint inversion of receiver functions and surface wave dispersion, J. Seismol., 17, 1321-1337.

Tezel, T., T. Shibutani and B. Kaypak (2013). Crustal thickness of Turkey determined by receiver function, J.Asian Earth Sci., 75, 36-45.

Tiberi, C., C. Ebinger, V. Ballu, G. Stuart and B. Oluma (2005). Inverse models of gravity data from the Red Sea-AdenEast African rifts triple junction zone, Geophys. J. Int., 163(2), 775-787.

Tiberi, C., S. Leroy, E. d'Acremont, N. Bellahsen, C. Ebinger, A. Al-Lazki and A. Pointu (2007). Crustal geometry of the northeastern Gulf of Aden passivemargin: localization of the deformation inferred from receiver function analysis, Geophys. J. Int., 168, 1247-1260.

Tikhonov, A.N. and V. Y. Arsenin (1977). Solutions of Ill-posed Problems, Scripta Series in Mathematics, Winston.

Uieda, L. (2015). A tesserioid (spherical prism) in a geocentric coordinate system with a local-North-oriented coordinate system.

Uieda, L. and C. F. V. Barbosa (2016). A gravity-derived Moho model for South America: source code, data, and model results from 'Fast non-linear gravity inversion in spherical coordinates with application to the South American Moho', 208(1).

Uieda, L., V. Barbosa and C. Braitenberg (2016). Tesseroids: forwardmodeling gravitational fields in spherical coordinates, Geophysics, 41-48. 


\section{Parastoo Jalooli et al.}

Uieda, L., V. C. Oliveira and V. C. F. Barbosa (2013). Modeling the Earth with Fatiando a Terra, in Proceedings of the 12th Python in Science Conference, Austin, Texas, USA, 91-98.

Van der Meijde, M., S. Van der Lee and D. Giardini (2003). Crustal structure beneath broad-band seismic stations in the Mediterranean region, Geophys. J. Int., 152, 729-739.

Wild-Pfeiffer, F. (2008). A comparison of different mass elements for use in gravity gradiometry, J. Geod., 82(10), 637653.

Zhu, L., B. J. Mitchell, N. Akyol, I. Cemen and K. Kekovali (2006). Crustal thickness variations in the Aegean region and implications for the extension of continental crust, J. Geophys. Res., 111(B1).

*CORRESPONDING AUTHOR: Hossein ZOMORRODIAN,

Department of Earth Sciences, Science and Research Branch, Islamic Azad University, Tehran, Iran, h.zomorrodian@srbiau.ac.ir (c) 2020 the Istituto Nazionale di Geofisica e Vulcanologia. All rights reserved 